\title{
ARROWLEAF CLOVER (Trifolium vesiculosum Savi): A NEW SPECIES OF ANNUAL LEGUMES FOR HIGH RAINFALL AREAS OF THE MEDITERRANEAN CLIMATE ZONE OF CHILE
}

\author{
Carlos Ovalle M. ${ }^{*}$, Alejandro del Pozo² ${ }^{2}$ Fernando Fernández ${ }^{3}$,Jorge Chavarría ${ }^{1}$, \\ and Susana Arredondo ${ }^{1}$
}

\begin{abstract}
The present review examines the main attributes and agronomic characteristics of arrowleaf clover (Trifolium vesiculosum Savi) and its incorporation into production systems in dryland areas of the Andean foothills of the humid Mediterranean climate zone of Chile. It is a new species of annual legume in Chile for light and medium textured soils. The root system can reach a depth of $1.5 \mathrm{~m}$ and its seeds have a high percentage of hardseedness $(99.8 \%)$. It is an upright plant, with purplish-white flowers. The mature plant has large arrow-shaped leaves up to 50 $\mathrm{mm}$ long, often marked with a large white "V". Dry matter and seed production in the Andean foothills is high (3.9$8.8 \mathrm{t} \mathrm{DM} \mathrm{ha}^{-1}$ and 700-900 $\mathrm{kg} \mathrm{ha}^{-1}$, respectively), surpassing the productivity of sub clover (Trifolium subterraneum L.) cv. Mount Barker and crimson clover (Trifolium incarnatum L.). However, DM production in the second year was lower, possibly because the high percentage of hardseedness inhibited plant emergence. The phenological records and productive performance suggest that arrowleaf clover could contribute to improving pastoral production in dryland areas with annual rainfall levels of more than $800 \mathrm{~mm}$, such as the Andean foothills in the central-southern region of Chile.
\end{abstract}

Key words: Trifolium vesiculosum, arrowleaf clover, annual legume pastures, dryland Andean foothills, Mediterranean pastures.

\section{INTRODUCTION}

Historically, seeding Mediterranean climate pastures in Chile has been characterized by a limited diversity of species and cultivars in the market. From the 1950s until only a few years ago, the subterranean clover (Trifolium subterraneum L. sensu lato), and the crimson clover ( $T$. incarnatum L.) were the most important annual legumes for forage. By the late 1980s work began to domesticate the naturalized Chilean germplasm of burr medic (Medicago polymorpha L.) (Ovalle et al., 1997a; 2001; del Pozo et al., 2001; 2002) and seeds were commercially available in Chile from 1995. Later, balansa clover (T. michelianum Savi) was introduced in 1997 and sold commercially. This species is highly tolerant to water logging and therefore

'Instituto de Investigaciones Agropecuarias INIA, Casilla 426, Chillán, Chile. "Corresponding author (covalle@inia.cl).

${ }^{2}$ Universidad de Talca, Facultad de Ciencias Agrarias, Casilla 747, Talca, Chile.

${ }^{3}$ Instituto de Investigaciones Agropecuarias INIA, Casilla 165, Cauquenes, Chile.

Received: 02 October 2008.

Accepted: 29 April 2009. suitable for clay soils with problems of inundation during winter (Ovalle et al., 1997b). Diversification of fodder legumes has continued with the introduction of the yellow and pink serradellas (Ornithopus compressus L. and $O$. sativus Brot.) (Rojas et al., 2002; Ovalle et al., 2003; 2006) and the biserrula (Biserrula pelecinus L.) (Ovalle et al., 2004). Nevertheless, of these last three species, only $O$. sativus cv. Cádiz is available in the national market for mixed fodder.

New species of fodder legumes suitable for environments of high precipitation and low temperatures during late autumn-winter are required for areas like the Andean foothills of Chile. With an altitude between 300 and 600 m.a.s.1, deep trumaos soils, a humid Mediterranean type climate with an annual rainfall of over $1100 \mathrm{~mm}$, the Andean foothills have the strongest potential for livestock of any area in central southern Chile. Despite the natural potential, this advantage has not yet been utilized by livestock producers, because of the low productivity of existing pastures. Systems of calf and sheep-raising are based more on the use of stubble or natural pasture than on self-seeding between the two sequences of cereal crops. Moreover, in intensive 
rotations of wheat (Triticum aestivum L.) and oats (Avena sativa L.), or wheat and rapeseed (Brassica napus L.), there is no space for good pastures capable of sustaining productive and profitable livestock (Rodríguez et al., 1992). Consequently, alternative grasslands are required and the arrowleaf clover (Trifolium vesiculosum Savi), recently introduced to the country, could be an interesting option for integration into productive systems in the humid Mediterranean zone.

The present review describes the main attributes and agronomic characteristics of the arrowleaf clover and analyzes the productivity and persistence of this species in volcanic and slightly acidic soils in the humid Mediterranean zone of Chile.

\section{CHARACTERISTICS OF THE PLANT AND ITS IMPORTANCE AS A CROP}

The arrowleaf clover is an annual legume, originating from the Balkan Peninsula, the Crimea and the Caucus (Duke, 1981; Oram, 1990; Evans, 2006). It is currently distributed over a much wider area in Europe and western Asia, in countries such as Greece, Turkey, the Ukraine and southern Russia (Thompson, 2005). The plant is semierect with hollow stems of up to $1.5 \mathrm{~cm}$ in diameter and large trifoliate leaves, arrow-shaped, with a large V-shaped white mark. The flowers are purplish-white. Flowering period is extended for 1-2 months. Reproduction is by cross-pollination by bees. The seeds are brown, yellow or green and weigh around $1.2 \mathrm{mg}$, which is slightly more than the seeds of the balansa or Persian clovers, but less than those of T. incarnatum, T. subterraneum or
T. hirtum All. One of its main characteristics is a taproot system $(1.5 \mathrm{~m})$ which allows to extract nutrients and water from deeper soil layers, extending its growth period and allowing it to remain green for longer than any other annual pasture species or traditional legumes (Oram, 1990; Thompson, 2005; Loi et al., 2005; Evans, 2006). The roots of the arrowleaf clover extend 20 to $25 \%$ deeper than the roots of the subterranean clover, reaching a depth of 0.8 to $1.5 \mathrm{~m}$ (Loi et al., 2005).

The arrowleaf is adapted to a wide range of soils. However, the best results have been obtained in well drained soils that are neutral or acidic, with a $\mathrm{pH}$ of 6.0 to 7.0 (Caddel and Redmon, 1995; Evans, 2006). Nevertheless, there are cultivars that withstand up to $\mathrm{pH}$ 4.5 (Oram, 1990; Snowball et al., 2005; Evans, 2006). When it is planted in calcareous soils it presents chlorosis, which is a symptom of Fe deficiency (Frame, 2007). It does not tolerate soils with poor drainage (Gibberd $e t$ al., 2001) and is extremely sensitive to edaphic salinity (Rogers et al., 2007).

It is the most important annual clover cultivated in the USA, covered 2.5 times as many hectares as the crimson clover, which is the second most important species in the country (Evans, 2006; Frame, 2007). It is used there mainly as winter pasture and cover crop. It is also an important species in western Australia, as well as countries in Mediterranean Europe (Rizzo, 1995; Restle et al., 2000; Snowball et al., 2005), Uruguay, Brazil and Portugal. Its importance and advantage against subterranean clover lies in the fact that flowers and seeds are develop on the top of the canopy facilitating seed harvest by combine harvester (Evans, 2006).

Table 1. Phenology of Trifolium vesiculosum cv. Seelu in comparison to other Mediterranean fodder legume species studied in Chile.

\begin{tabular}{llccc}
\hline Species & $\begin{array}{c}\text { Cultivar or } \\
\text { accession }\end{array}$ & $\begin{array}{c}\text { Days to } \\
\text { first bloom }\end{array}$ & $\begin{array}{c}\text { Days to first } \\
\text { fruit }\end{array}$ & $\begin{array}{c}\text { Days to } \\
\text { maturation }\end{array}$ \\
\hline Medicago polymorpha & Cauquenes INIA & $111 \pm 2.3 \mathrm{P}$ & $129 \pm 2.3$ & $174 \pm 4.4$ \\
Ornithopus compressus & Madeira & $124 \pm 4.0 \mathrm{I}$ & $136 \pm 0.6$ & $179 \pm 6.4$ \\
O. compressus & Ávila & $143 \pm 6.4 \mathrm{~T}$ & $156 \pm 2.0$ & $190 \pm 2.3$ \\
O. sativus & Cádiz & $135 \pm 1.7 \mathrm{~T}$ & $147 \pm 0.0$ & $182 \pm 0.0$ \\
Trifolium michelianum & Paradana & $136 \pm 2.3 \mathrm{~T}$ & $150 \pm 2.3$ & $172 \pm 0.6$ \\
T. resupinatum & Kymbro & $153 \pm 2.3 \mathrm{MT}$ & $162 \pm 2.0$ & $185 \pm 3.5$ \\
T. subterraneum & Seaton Park & $111 \pm 2.3 \mathrm{P}$ & $125 \pm 2.3$ & $189 \pm 4.0$ \\
T. subterraneum var. yanninicum & Gosse & $127 \pm 2.3 \mathrm{I}$ & $136 \pm 0.6$ & $187 \pm 5.7$ \\
T. subterraneum var. brachycalycinum & Clare & $130 \pm 2.3 \mathrm{I}$ & $154 \pm 3.5$ & $188 \pm 2.3$ \\
T. subterraneum & Mount Barker & $140 \pm 9.1 \mathrm{~T}$ & $152 \pm 4.0$ & $195 \pm 3.5$ \\
T. vesiculosum & Seelu & $\mathbf{1 6 0} \pm \mathbf{4 . 6}$ MT & $\mathbf{1 7 5} \pm \mathbf{3 . 0}$ & $\mathbf{2 0 0} \pm \mathbf{2 . 3}$ \\
\hline
\end{tabular}

Values are averages of three replicates \pm standard deviation.

${ }^{1}$ Precocity classification (days to blooming): MP: very early (< 101); P: early (102-117); I: intermediate (118-133); T: late (134-149); MT: very late (150-165).

Source: Ovalle et al. (2003). 


\section{AGRONOMIC CHARACTERISTICS}

\section{Phenology}

The arrowleaf is one of the most recent clovers introduced in Mediterranean Chilean environments by the Instituto de Investigaciones Agropecuarias, INIA (Ovalle et al., 2003). Assessments made in the sub-humid Mediterranean zone around Cauquenes $\left(35^{\circ} 58^{\prime} \mathrm{S} ; 72^{\circ} 17^{\prime} \mathrm{W}\right.$; mean precipitation $657 \mathrm{~mm}$ ) showed 160 days from emergence to flowering for cv. Seelu, which is 20 days longer than the subterranean clover cv. Mount Barker (Ovalle et al., 2003) (Table 1). Another cultivar, Zulu II, has similar phenology to cv. Seelu. According to evaluation conducted in Australia, cv. Cefalu emergences 20 days before the two cultivars mentioned above (Snowball et al., 2005).

\section{Growth and phytomass production}

Seedlings vigor during establishment is high however winter growth is lower compared with other species of the genus Trifolium (Caradus, 1994; Evers, 1999). In Australia, arrowleaf clover has lower winter production than the subterranean clover, balansa clover and Persian clover (T. resupinatum L.), however spring production is higher (Evans, 2006). Also in Australia, dry matter production of arrowleaf clover cv. Arrotas (between September 15th and November 25th) was $9.6 \mathrm{t} \mathrm{MS} \mathrm{ha}^{-1}$, which was significantly higher than that of balansa clover cv. Bolta (6.1 t MS ha-1), Persian clover cv. Nitro (6.4 t MS ha-1) or subterranean clover cv. Leura (1.1 t MS ha-1) (Riffkin et al., 2001).

Evaluations conducted in the Andean foothills of Chile $\left(36^{\circ} 49^{\prime} \mathrm{S}, 71^{\circ} 45^{\prime} \mathrm{W}, 340\right.$ m.a.s.l., mean precipitation of $1100 \mathrm{~mm}$ ) between 2000 and 2003, arrowleaf clover cv. Seelu produced $3.9 \mathrm{t} \mathrm{DM} \mathrm{ha}^{-1}$ in the year of establishment, being significantly higher $(\mathrm{P} \leq 0.05)$ than that of subterranean clover cv. Mount Barker (Table 2). Production in the second season was lower because its high percentage of hard seeds, but in the third growing season production increased to $4.9 \mathrm{t} \mathrm{MS} \mathrm{ha}^{-1}$, similar to that of the yellow serradella cv. Ávila, and much higher than that of Mount Barker (Table 2). In another trial in the same area, the average dry matter production of arrowleaf clover cv. Zulu II on two consecutive years (2005 and 2006) was $8.2 \mathrm{t}$ dry matter ha-1, surpassing the production of subterranean and crimson clover (Table 3 ). The frost tolerance is apparently high since only $10 \%$ of the plants exhibited frost damage, which was slightly superior to the $3 \%$ observed in subclover cv. Mount Barker (Ovalle et al., 2005).

The arrowleaf clover presented high nodulation (100\% of the plants) in volcanic soils (Ovalle et al., 2005) and probably a high capacity for fixing N. Studies in Australia report production levels of $16.7 \mathrm{~kg} \mathrm{~N} \mathrm{t}^{-1} \mathrm{MS}$ (Bowman et al., 2004).

\section{Nutritive value}

Arrowleaf clover forage has a high palatability and nutritive value (Tekeli et al., 2005). The crude protein content, especially in full foliation, varies between 15 and 22\% in the Australian cultivars Cefalu, Seelu, Zulu II and Arrotas (Riffkin et al., 2001; Snowball et al., 2005). The variation in crude protein content of $\mathrm{cv}$. Arrotas between winter and summer was 29.9 to $15.6 \%$, and the digestibility of dry matter varied between 77.8 and $53.8 \%$, respectively (Riffkin et al., 2001). Digestibility decreased with maturity, associated with increased fiber content and the stem: leaf ratio. Data obtained in the Andean foothills indicate that at flowering the crude protein content is $22.3 \%$ crude protein, $22 \%$ of acid detergent fiber, and 2.4 Mcal kg-1 of metabolized energy (Hahn, 2007).

Table 2. Phytomass production in arrowleaf clover over three season (2000-2002) in comparison to other clovers, in the Andean foothills of the Bío Bío Region.

\begin{tabular}{|c|c|c|c|c|c|}
\hline \multirow[b]{2}{*}{ Species } & \multirow[b]{2}{*}{ Cultivar } & \multicolumn{4}{|c|}{ Dry matter } \\
\hline & & 2000 & 2001 & 2002 & Total \\
\hline & & $\longrightarrow$ & $-\mathrm{t}$ & - & . \\
\hline Ornithopus compressus & Ávila & $3.049 \mathrm{~b}^{1}$ & $1.691 \mathrm{bc}$ & $5.190 \mathrm{a}$ & $9.930 \mathrm{a}$ \\
\hline O. compressus & Madeira & $1.224 \mathrm{c}$ & $2.036 \mathrm{~b}$ & $4.785 \mathrm{a}$ & $8.045 b$ \\
\hline O. sativus & Cadiz & $1.555 \mathrm{c}$ & $2.537 \mathrm{ab}$ & $0.271 \mathrm{~d}$ & $4.363 d$ \\
\hline Trifolium subterraneum & M. Barker & $2.583 b$ & $2.154 \mathrm{ab}$ & $3.280 \mathrm{~b}$ & $8.017 \mathrm{~b}$ \\
\hline T. michelianum & Paradana & $1.018 \mathrm{c}$ & $2.825 \mathrm{a}$ & $1.861 \mathrm{c}$ & $5.704 \mathrm{c}$ \\
\hline T. resupinatum & Kymbro & $1.661 \mathrm{c}$ & $1.229 \mathrm{c}$ & $1.169 \mathrm{c}$ & $4.059 \mathrm{~d}$ \\
\hline T. vesiculosum & Seelu & $3.916 a$ & $0.625 \mathrm{c}$ & $4.876 a$ & $9.417 a$ \\
\hline
\end{tabular}

${ }^{1}$ Different letters in the same column indicate differences according to Duncan test $(\mathrm{P} \leq 0.05)$.

Source: Ovalle et al. (2005). 
Table 3. Biomass production in arrowleaf clover in comparison to other annual clovers, in the Andean foothills of the Bío Bío Region, during the seasons 2005 and 2006.

\begin{tabular}{llll}
\hline & & & Dry matter \\
\cline { 3 - 4 } Species & Cultivar & $\mathbf{2 0 0 5}$ & $\mathbf{2 0 0 6}$ \\
\hline & & & $\mathrm{tha}^{-1} \mathrm{yr}^{-1}$ \\
\cline { 3 - 4 } Trifolium vesiculosum & Zulu II & $\mathbf{8 . 8 3 0 \mathbf { a } ^ { 1 }}$ & $\mathbf{7 . 5 8 6 a b}$ \\
$T$. incarnatum & Corriente & $3.378 \mathrm{c}$ & $3.372 \mathrm{~d}$ \\
$T$. subterraneum & Mount Barker & $0.6204 \mathrm{~b}$ & $4.580 \mathrm{~cd}$ \\
$T$. subterraneum & Antas & $7.322 \mathrm{ab}$ & $6.298 \mathrm{bc}$ \\
$T$. subterraneum & Denmark & $4.066 \mathrm{c}$ & $4.681 \mathrm{~cd}$ \\
\hline
\end{tabular}

${ }^{1}$ Different letters in the same column indicate differences according to Duncan test $(\mathrm{P} \leq 0.05)$.

Source: Hahn (2007).

\section{Seed production and hardseedness}

In the Andean foothills seed yield of arrowleaf clover was higher than other annual legume species in seed production, exceeding $700 \mathrm{~kg} \mathrm{ha}^{-1}$ in the year of establishment (Table 4), which ensure a seed back for the following years. Because of the high percentage of hardseedness (99\%, Ovalle et al., 2003) and persistence after a crop face (Loi et al., 2005; Tonitto et al., 2006; Evans, 2006), the arrowleaf clover is very appropriate for rotation systems with cereals or rapeseed, like the productive systems prevalent in the Andean foothills.

\section{ESTABLISHMENT AND MANAGEMENT}

The species can be established with direct seeding in a level soil with adequate moisture (Overman et al., 1992). Seeding can be from the end of summer, with dry seeding, until early autumn with conventional seeding. The key for a good establishment in the Andean foothills, an area with frequent frosts, is, to sow as early as possible to reduce the risk of dislodging emerging seedlings. The temperature should be at least $15{ }^{\circ} \mathrm{C}$ for a good germination and development of seedlings (Evers, 1980). The recommended seed doses, first scarified and inoculated, is $7-11 \mathrm{~kg} \mathrm{ha}^{-1}$ (Miller and Wells, 1985; Evans, 2006), which should be planted at a depth of no more than $1 \mathrm{~cm}$. Between 3 and $6 \mathrm{~kg} \mathrm{ha}^{-1}$ is also recommended to establish a pasture with a mix of other annual legumes, such as subterranean clover, or in association with grasses. For seed production 5 to $10 \mathrm{~kg} \mathrm{ha}^{-1}$ is recommended and 10 to $20 \mathrm{~kg} \mathrm{ha}^{-1}$ is recommended for production of hay or silage (Snowball et al., 2005).

If arrowleaf clover is seeded in a mix with short-cycle annual ryegrass (Lolium multiflorum Lam.), it is advisable to use a low doses of grass seed to avoid excessive competition for grazing during the winter. In areas with high rainfall it is recommended planting a perennial ryegrass (Lolium perenne L.), given that it would be less competitive. Winter production can be increased by the presence of the grass and the clover makes an excellent late contribution in the spring until the beginning of winter (Evans, 2006).

The plants that best adapt to intensive grazing systems are those with a creeping growth habit, such as subterranean clover (Evers and Newman, 2008; Ovalle et al., 2008), many composite species and those of the genus Erodium, as well as stoloniferous and rhizomatous plants (del Pozo et al., 2006). These plants are capable of maintaining a foliar area compatible with photosynthesis requirements, even when they are intensely grazed. Consequently, they are able to grow back rapidly after cutting or grazing. In contrast, fodder plants with erect growth, such as arrowleaf clover, balansa clover, Trifolium glanduliferum Boiss. or serradela, are less tolerant of grazing given that the majority of leaves (and stems) are easily consumed by the animals, affecting their capacity to re-grow (Evers and Newman, 2008; Ovalle et al., 2008).

In a experiment comparing the effect of the season and the number of cuttings on phytomass production of different annual legumes, total phytomass production in two subterranean clover cultivars and T. glanduriferum did not differ statistically in comparison to a treatment that was cut only once at the end of the season, owing to the relatively high capacity of these species for recuperation (Ovalle et al., 2008). But late cutting did affect the recovery and consequently total phytomass production of erect growing legumes such as the arrowleaf clover, balansa clover and serradela (Ovalle et al., 2008). High seed yield were determined in uncut pastures of arrowleaf clover and balansa clover, but a delay in cutting from 9 September to 24 October had a notable reduction in seed production, particularly in arrowleaf clover, balansa clover and T. glanduliferum. These three species have delayed phenology, with respectively 141 and 130 days from seeding to flowering (Ovalle et al., 2003). The least affected by the cutting 
Table 4. Seed production of arrowleaf clover, in comparison to other annual clovers, in the Andean foothills of the Bío Bío Region, during the seasons 2000 and 2001, and 2005.

\begin{tabular}{llccc}
\hline & & \multicolumn{3}{c}{ Seed production } \\
\cline { 3 - 5 } Species & Cultivar & $\mathbf{2 0 0 0}$ & $\mathbf{2 0 0 1}$ & $\mathbf{2 0 0 5}$ \\
\cline { 3 - 5 } $\mathrm{kg} \mathrm{ha}^{-1} \mathrm{yr}^{-1}$ & \\
Trifolium subterraneum & Mount Barker & $690 \mathrm{~b}$ & $610 \mathrm{a}$ & $352 \mathrm{~b}^{1}$ \\
Ornithopus compressus & Ávila & $250 \mathrm{c}$ & $280 \mathrm{~b}$ & $682 \mathrm{a}$ \\
T. vesiculosum & Zulu II & $\mathbf{8 9 0 a}$ & $\mathbf{5 0 0 a b}$ & $\mathbf{7 3 4 a}$ \\
T. incarnatum & Corriente & - & - & $224 \mathrm{~b}$ \\
\hline
\end{tabular}

${ }^{1}$ Different letters in the same column indicate differences according to Duncan test $(\mathrm{P} \leq 0.05)$.

Source: Hahn (2007).

season were the subterranean clover (cvs. Antas and Seaton Park) and burr medic, which had the same or higher levels of production at $100 \mathrm{~g} \mathrm{~m}^{-2}$ when cutting was carried out on September 24th, and approximately $80 \mathrm{~g} \mathrm{~m}^{-2}$ when cuttings on October 9th. Similar results were observed in a study in Texas, USA, with arrowleaf phytomass production of $2480 \mathrm{~g} \mathrm{~m}^{-2}$ in treatments with only one cutting at the end of the season; production decreased significantly when there were two cuttings, except in the case of subterranean clover, which increased production with the cuttings owing to it habit of prostrate growth (Evers and Newman, 2008).

In summary, for the appropriate grazing management, there should be a balance between the efficient use of forage and seed production, given that the latter is the basis for regenerating and persistence of the pasture. In order to maximize the seed bank it is necessary, overall in the first year, not to graze the clover pasture from the beginning of flowering until the end of spring. Close to maturity, when the nutritive value is still high (end of January-February) the pasture should be grazed when the seeds are already dry. The optimal level of residual forage should be near to zero at the beginning of the first autumn rains in order to achieve better regeneration. Heavy summer grazing should not affect the seed bank given that a high percentage of the seeds survive passage through the digestive tracks of the animals and consequently return intact to the soil. The species is highly palatable as pasture forage, hay or silage (Evans, 2006).

\section{Forage conservation}

Its rapid growth in spring and the beginning of summer, its habit of erect growth, its good recovery after cutting and its high digestibility, all make the arrowleaf clover appropriate for hay and silage. In zones with high precipitation and long growing seasons, growth is sufficient for two cuttings without severely affecting the seed bank. The arrowleaf clover has good growth after cutting for hay or silage (Evans, 2006).

\section{DESCRIPTION OF CULTIVARS}

Four cultivars are currently being marketed in Australia, of which Cefalu is early flowering, Seelu and Zulu II are late flowering, and Arrotas is classified as very late flowering. In the USA the cultivar Yuchi is early flowering, Amclo is intermediate, and Meechee late (Hoveland, 1995). Here we only describe briefly the Australian cultivars that eventually can be available in Chile. Three of these (Seelu, Zulu II and Cefalu) have been assessed in the INIA Mediterranean forage program.

\section{Cefalu}

Cefalu grows around Perth in Western Australia (31 ${ }^{\circ} 96^{\prime}$ S; $115^{\circ} 84^{\prime}$ W). It flowers 135 days after seeding, approximately two weeks before 'Seelu' and 'Zulu II' and six weeks before cv Arrotas, (Snowball et al., 2005). Phenological assessments of this cultivar in Chile indicate a similar behavior to that in Australia, with 140 days between emergence and flowering (Ovalle et al., 2007). It has an early prostrate growth, but is erect during the spring; reaching a height of $1.2 \mathrm{~m}$. Cefalu produces thick stems and large leaves. It has deep roots that extend to a depth of $1.5 \mathrm{~m}$, which results in it producing forage for much longer than other grasses, giving it an added value. It has a high level of seed production and a high percentage of hard seeds, which makes it an excellent alternative for rotation with other crops. Cefalu is adapted to zones with more than $400 \mathrm{~mm}$ of precipitation annually. It is highly tolerant to acidic soils (pH 4.5) but is not tolerant of prolonged conditions of water-logging or heavy soils. Cefalu can be used as hay, silage or green manure (Seedmark, 2005a; Snowball et al., 2005).

\section{Seelu}

Seelu is a late maturing cultivar. It flowers in Cauquenes, in the dry interior of Chile, 160 days after seeding. It shows good growth during the spring and beginning 
of the summer, providing excellent forage production. Seelu grows erect with heights of 50 to $100 \mathrm{~cm}$ and is appropriated for association with perennial grasses. It is easily harvested either as forage or for it seeds. Seelu adapts to zones with annual precipitation levels of over $800 \mathrm{~mm}$ (Evans, 2006).

\section{Zulu II}

Zulu II is a semi-late cultivar that is very similar to Seelu. It flowers in Perth (Western Australia) 162 days after seeding. It has a prostrated early growth, beginning to be erect in the spring and reaching a height of 1.2 $\mathrm{m}$. Zulu II has deep roots that can reach a depth of 1.5 $\mathrm{m}$, which allows it to extend its growth period during the summer. It has a high level of seed production and a high percentage of hard seeds, so that it can be used in rotation with other crop. It can adapt to areas with more than $450 \mathrm{~mm}$ of precipitation annually. Zulu II has excellent tolerance to acidic soils ( $\mathrm{pH} 4.5$ to 7.0 ) but is intolerant of water-logging conditions and heavy soils. It can be used as hay, silage or green manure, with a crude protein content of 18-22\% (Seedmark, 2005b; Thompson, 2005).

\section{Arrotas}

Arrotas is a new late cultivar developed in Tasmania, Australia, originating from collections in Italy. Its main characteristic is that it takes better advantage of the long growing season in humid Mediterranean areas than any other leguminous species. Arrotas flowers six weeks after cv. Cefalu. It is highly productive until the

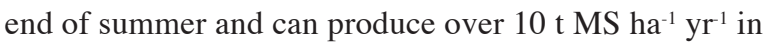
Hamilton $\left(37^{\circ} 73^{\prime} \mathrm{S} ; 142^{\circ} 02^{\prime} \mathrm{W}\right)$, Victoria, Australia. It does not produce meteorism in animals. It is moderately tolerant of the cold, sustaining temperatures to $-5{ }^{\circ} \mathrm{C}$. It is not tolerant to salinity or poor drainage. The seeds are relatively small, the weight of 1,000 seeds is $1.42 \mathrm{~g}$. Seminal hardness is $96 \%$, because of which scarification is necessary before seeding (Riffkin et al., 2001; Thompson, 2005).

\section{CONCLUSIONS}

The arrowleaf clover presents characteristics of tolerance to cold, delayed phenology, high level of seed and phytomass production, small seeds with a high hardseedness, and a strong capacity for fixing nitrogen. All of these are very appropriate attributes that suggest the arrowleaf clover can be successfully integrated into cattle production systems in humid Mediterranean areas. In particular, it could become an important support in areas of the Andean foothills in the central south and south of Chile, where in five years of assessment it has shown superiority in terms of phytomass and seed production compared to subterranean clover and crimson clover. Arrowleaf clover is more productive and persistent than crimson clover. It is also considered appropriate for both cutting and grazing. However, its erect habit with flowers and seeds developing at the top of the canopy, and its incapacity to bury the seeds, makes it more vulnerable to grazing than subterranean clover, requiring to prevent grazing during the flowering period. Consequently, it seems advisable to integrate it into grazing system in a mix and not as the only species in the pasture. The data available to date on phytomass and seed production make it suitable in Mediterranean climates with annual precipitation levels above 800 $\mathrm{mm}$. Another relevant trait is hardseedness so it can be incorporated as a annual pasture in rotation with cereal or oleaginous crops. It can also be incorporated in association with annual or perennial grasses and other legumes as permanent pasture.

\section{ACKNOWLEDGEMENTS}

We thank FONDECYT 1000608 for funding part of this research.

\section{RESUMEN}

Trébol vesiculoso (Trifolium vesiculosum Savi): Una nueva especie de leguminosa anual para áreas de alta precipitación en la zona mediterránea de Chile. En la presente revisión se examinan los principales atributos y características agronómicas del trébol vesiculoso (Trifolium vesiculosum Savi) y su eventual incorporación a sistemas de producción en la precordillera andina de la zona de clima mediterráneo húmedo de Chile. Se trata de una nueva especie de leguminosa forrajera anual para suelos de textura liviana y media. El sistema radical puede alcanzar $1,5 \mathrm{~m}$ de profundidad y las semillas tienen un alto porcentaje de dureza seminal $(99,8 \%)$. Es una planta de crecimiento erecto, flores de color blanco con una leve coloración púrpura. Las plantas adultas tienen grandes hojas con forma de flecha de más de $50 \mathrm{~mm}$ de largo, a menudo muestran una marca blanca en forma de "V". La producción de materia seca y de semillas en precordillera andina es alta (3,9-8,8 $\left.\mathrm{t} \mathrm{MS} \mathrm{ha-} \mathrm{año}^{-1}\right)$, superando el rendimiento alcanzado por el trébol subterráneo (Trifolium subterraneum L.) cv. Mount Barker y el trébol encarnado (T. incarnatum L.). Sin embargo, la producción del segundo año puede ser inferior dado que el alto porcentaje de dureza seminal inhibe la emergencia de plantas ese año. Los antecedentes de fenología y comportamiento productivo sugieren que el trébol vesiculoso podría contribuir al 
mejoramiento de la producción pastoral en zonas de secano con precipitaciones anuales superiores a $800 \mathrm{~mm}$, como en la precordillera andina de la zona centro-sur de Chile.

Palabras clave: Trifolium vesiculosum, trébol vesiculoso, praderas de leguminosas anuales, secano de precordillera andina.

\section{LITERATURE CITED}

Bowman, A.M., W. Smith, M.B. Peoples, and J. Brockwell. 2004. Survey of the productivity, composition and estimated inputs of fixed nitrogen by pastures in central-western New South Wales. Aust. J. Exp. Agric. 44:1165-1175.

Caddel J., and L. Redmon. 1995. Arrowleaf clover. Forage crops - Production technology. Oklahoma State University Vol. 7. $\mathrm{N}^{\circ} 13$.

Caradus, J.R. 1994. Frost tolerance of Trifolium species. N.Z. J. Agric. Res. 38:157-162.

Del Pozo, A., C. Ovalle, J. Aronson, and J. Avendaño. 2002. Ecotypic differentiation in Medicago polymorpha along an environmental gradient in central Chile. I. Phenology, winter vigor and biomass production. Plant Ecol. 159:119-130.

Del Pozo, A., C. Ovalle, J. Avendaño, T. Aravena, y M.E. Díaz. 2001. Combarbalá-INIA, un cultivar precoz de hualputra (Medicago polymorpha), para áreas de secano mediterráneo. Agric. Téc. (Chile) 61:93-96.

Del Pozo, A., C. Ovalle, M.A. Casado, B. Acosta, and J.M. De Miguel. 2006. The influence of grazing intensity on species composition and productivity in Mediterranean grasslands of central Chile. J. Veg. Sci. 17:791-798.

Duke, J.A. 1981. Handbook of legumes of world economic importance. p. 181-267. Plenum Press, New York, USA.

Evans, P. 2006. Arrowleaf clover. Agriculture Notes. State of Victoria, Department of Primary Industries. 2 p. Available at http://www.dpi.vic.gov.au/dpi/nreninf. nsf/v/2C74CA45607D05A2CA2574160076270F/\$fi le/Arrowleaf\%20Clover.pdf (accessed August 2007).

Evers, G.W. 1980. Germination of cool season annual clovers. Agron. J. 72:537-540.

Evers, G.W., and Y. Newman. 2008. Arrowleaf, crimson, rose, and subterranean clover growth with and without defoliation in the southeastern United States. Agron. J. 100:221-230.

Evers, G.W. 1999. Seedling growth comparison of arrowleaf, crimson, rose and subterranean clovers. Crop Sci. 39:433-440.
Frame, J. 2007. Trifolium vesiculosum Savi. FAO, Rome, Italy. Available at http://www.fao.org/AG/agp/agpc/ doc/gbase/DATA/Pf000504.HTM (accessed August 2007).

Gibberd, M., J. Gray, P. Cocks, and T. Colmer. 2001. Waterlogging tolerance among a diverse range of Trifolium accessions is related to root porosity, lateral root formation and 'aerotropic rooting'. Ann. Bot. (London) 88:579-589.

Hahn, C. 2007. Desarrollo de mezclas forrajeras para el mejoramiento de la productividad y persistencia de las praderas en áreas de precordillera andina de la zona Centro Sur de Chile. 51 p. Tesis Ingeniero Agrónomo. Universidad Adventista de Chile, Chillán, Chile.

Hoveland, C.S., and G.W.Evers. 1995. Arrowleaf, crimson and other annual clovers. p. 249-260. In Barnes, R.F., D.A. Miller, and C.J. Nelson (eds.) Forages. Vol. 1. An introduction to grassland agriculture. $5^{\text {th }}$ ed. Iowa State University Press, Ames, Iowa, USA.

Loi, A., J.G. Howieson, B.J. Nutt, and S.J. Carr. 2005. A second generation of annual pasture legumes and their potential for inclusion in Mediterranean-type farming systems. Aust. J. Exp. Agric. 45:289-299.

Miller, J.D., and H.D. Wells. 1985. Arrowleaf clover. p. 503-514. In Taylor, N.L. (ed.) Clover science and technology. ASA/CSSA/SSSA, Madison, Wisconsin, USA.

Oram, R.N. 1990. Register of Australian herbage plant cultivars. $3^{\text {rd }}$ ed. 303 p. Commonwealth Scientific and Industrial Research, East Melbourne, Victoria, Australia.

Ovalle, C., S. Arredondo, A. del Pozo, J. Avendaño, y F. Fernández. 2004. Atributos y antecedentes del comportamiento de Biserrula pelecinus L. Nueva leguminosa forrajera anual para Chile mediterráneo. Agric. Téc. (Chile). 64:74-81.

Ovalle, C., S. Arredondo, y O. Romero. 2006. Serradela amarilla (Ornithopus compressus) y serradela rosada (O. sativus): dos nuevas especies de leguminosas forrajeras anuales para la zona mediterránea de Chile. Agric. Téc. (Chile) 66:196-209.

Ovalle, C., A. Del Pozo, S. Arredondo, y J. Chavarría. 2005. Adaptación, crecimiento y producción de nuevas leguminosas forrajeras anuales en la zona mediterránea de Chile: I. Comportamiento de las especies en la precordillera andina. Agric. Téc. (Chile) 65:35-47.

Ovalle, C., A. Del Pozo, J. Avendaño, T. Aravena, y M.E. Díaz. 2001. Cauquenes-INIA, nuevo cultivar de hualputra chilena (Medicago polymorpha) para áreas de secano mediterráneo. Agric. Téc. (Chile) 61:89-92. 
Ovalle, C., A. Del Pozo, J. Avendaño, y J. Aronson. 1997a. Características fenológicas y productivas de 34 accesiones de hualputra (Medicago polymorpha) colectadas en la zona mediterránea de Chile. Agric. Téc. (Chile) 57:261-270.

Ovalle, C., A. Del Pozo, J. Avendaño, P. Bustos, y S. Arredondo. 2003. Caracterización preliminar de una colección de leguminosas forrajeras anuales para la zona mediterránea de Chile. Agric. Téc. (Chile) 63:156-168.

Ovalle, C., J. Chavarría, F. Fernández, y A. Del Pozo. 2007. Atributos y antecedentes del comportamiento de Trifolium vesiculosum Savi: nueva leguminosa forrajera anual para la precordillera andina. p. 6566. XXXII Reunión Anual de la Sociedad Chilena de Producción Animal (SOCHIPA), Frutillar. 14-16 noviembre. Libro de resúmenes. SOCHIPA, Santiago, Chile.

Ovalle, C., F. Fernández, y A. del Pozo. 2008. ¿Cómo manejar especies de leguminosas anuales de crecimiento erecto? Efecto de la época de utilización sobre la producción de fitomasa y semilla. 53-54. XXXIII Reunión Anual de la Sociedad Chilena de Producción Animal (SOCHIPA), Valdivia. 29-31 de octubre. Libro de resúmenes. SOCHIPA, Santiago, Chile.

Ovalle, C., F. Squella, S. Arredondo, A. del Pozo, y J. Avendaño. 1997b. Trébol balansa (Trifolium michelianum) una leguminosa forrajera promisoria para sistemas pastorales del secano mediterráneo de Chile. Agric. Téc. (Chile) 57:50-57.

Overman, A.R., S.R. Wilkinson, and G.W. Evers. 1992. Yield response of bermudagrass and bahiagrass to applied nitrogen and overseeded clover. Agron. J. 84:998-1001.

Restle, J., E. Dias, e J. Carvallo. 2000. Palha de trevo vesiculoso (Trifolium vesiculosum Savi cv. Yuchi) como substituto da silagem de milho na alimentação de novilhos confinados. Cienc. Rural 30:325-331.

Riffkin, P.A., P. Evans, and A. Wright. 2001. Extending pasture quality later into the season. Proceedings of the Australian Agronomy Conference, Australian Society of Agronomy. Available at http://www. regional.org.au/au/asa/2001/p/9/riffkin.htm (accessed August 2007).
Rizzo, D. 1995. Mejoramientos extensivos en el Uruguay. 6 p. XIV Reunión Grupo Campos. Instituto Nacional de Investigación Agropecuaria (INIA), Tacuarembó, Uruguay.

Rodríguez, N., F. Silva, y C. Belmar. 1992. Factores que inciden en la producción de trigo en la región centrosur. II. Rotaciones para los suelos de la precordillera andina. Agric. Téc. (Chile) 52:11-17.

Rogers, M.E., C.L. Noble, and R.J. Pederick. 1997. Identifying suitable temperate forage legume species for saline areas. Aust. J. Exp. Agric. 37:639-645.

Rojas, C., O. Romero, y L. Barrientos. 2002. Producción de carne bovina en praderas naturalizadas de serradela amarilla (Ornithopus compressus L.) y trébol subterráneo (Trifolium subterraneum L.) en condiciones de secano de la IX Región, Chile. Agric. Téc. (Chile) 62:519-529.

Seedmark. 2005a. Arrowleaf clover. Cefalu. Seed Technology \& Marketing Pty, Hilton, South Australia. Available at http://www.seedmark.com.au/files/ annual-clover_cefalu.pdf (accessed August 2007).

Seedmark. 2005b. Arrowleaf clover. Zulu II. Seed Technology \& Marketing Pty, Hilton, South Australia. Available at http://www.seedmark.com.au/files/ annual-clover_zuluII.pdf (accessed August 2007).

Snowball, R., T. Wiley, and C. Revell. 2005. Cefalu arrowleaf clover. Farmnote. Department of Agriculture $N^{\text {o } 38 . ~} 4$ p. State of Western Australia, South Perth, Western Australia, Australia.

Thompson, R.B. 2005. Arrowleaf clover. Primefact 102. 6 p. Profitable \& Sustainable Primary Industries, West Wyalong, Australia. Available at http://www.dpi.nsw. gov.au/_data/assets/pdf_file/0009/48816/arrowleaf_ clover_-_primefact_102-final.pdf (accessed August 2007)

Tekeli, A., E. Ates, and F. Varol. 2005. Nutritive values of some annual clovers (Trifolium sp.) at different growth stages. J. Cent. Eur. Agric. 6:323-330.

Tonitto, C., M.B. David, and L.E. Drinkwatera. 2006. Replacing bare fallows with cover crops in fertilizerintensive cropping systems: A meta-analysis of crop yield and $\mathrm{N}$ dynamics. Agric. Ecosyst. Environ. 112:58-72. 